\title{
PELAKSANAAN PENGEMBALIAN KERUGIAN KEUANGAN NEGARA (ASSET RECOVERY) DALAM TINDAK PIDANA KORUPSI \\ (Studi Kasus Kejaksaan Tinggi Sumatera Barat)
}

\section{ASSET RECOVERY IMPLEMENTATION ON CORRUPTION CASE (A Case Study of High Court of West Sumatera)}

\author{
Rustam \\ Program Studi Ilmu Hukum Fakultas Hukum \\ Universitas Riau Kepulauan, Batam, Indonesia \\ fendy_harjo@yahoo.com
}

\begin{abstract}
Abstrak
Kerugian keuangan negara yang ditimbulkan akibat tindak pidana korupsi sungguh luar biasa. Bagaimana keuangan negara yang seharusnya digunakan untuk mensejahterakan rakyatnya, ternyata telah diselewengkan oleh sebagian orang yang tak bertanggungjawab untuk menambah kekayaannya. Metode penelitian ini dilakukan adalah deskriptif yaitu cara penelitian yang menggambarkan secara lengkap dan jelas tentang persoalan yang diteliti dengan pendekatan yuridis sosiologi terhadap penerapan hukum di lapangan oleh penegak hukum. data diperoleh dari dat primer dan data sekunder melalui penelitian lapangan dan penelitian kepustakaan. Hasil penelitian menunjukan bahwa: a) Pelaksanaan pengembalian kerugian keuangan negara di Kejaksaan Tinggi Sumatera Barat lebih cenderung untuk menunggu putusan hakim yang telah berkekuatan hukum tetap, itupun tidak berhasil dilakukan secara maksimal dikarenakan lemahnya sumberdaya manusia dan lemahnya hukum yang berkaitan dengan pengembalian kerugian keuangan negara, b) hambatan dalam pengembalian kerugian keuangan negara antara lain adanya perlawanan dari pihak keluarga tersangka, terpidana tidak sanggup membayar kerugian keuangan negara sebagaimana yang telah disebutkan dalam putusan hakim, dan terpidana meninggal dunia.
\end{abstract}

Kata Kunci : Asset Recovery, Korupsi

\section{Abstract}

The state financial losses incurred by corruption were extraordinary. How the state finances that should be used for the prosperity of its people, it had been distorted by some people who were not responsible for adding their wealth. The method of this research was descriptive which described completely and clearly about the problem under study with approach of sociology juridical to law enforcement in field by law enforcer. data were obtained from primary data and secondary data through field research and library research. The result of the research shows that: a) The implementation of state financial loss recovery in High Court of West Sumatera is more likely to await the verdict of judge which has a permanent legal force, and even then cannot be done maximally due to weakness of human resources and weakness of law relating to state financial loss return, $b$ ) obstacles in the state financial loss recovery was the existence of resistance from the suspect's family, the convicted person can not afford to pay the state financial loss as mentioned in the judge's decision, and the convicted person died.

Keywords: Asset Recovery, Corruption 


\section{PENDAHULUAN}

Dalam Undang-undang Dasar Negara Republik Indonesia Tahun 1945 ditegaskan bahwa negara Indonesia berdasarkan atas hukum (rechtstaat), tidak berdasarkan atas kekuasaan belaka (machtstaat). Ini berarti bahwa Negara Kesatuan Republik Indonesia adalah negara hukum, yang demokratis berdasarkan Pancasila dan Undang-undang Dasar RI 1945, menjunjung tinggi hak asasi manusia, dan menjamin semua warga negara bersamaan kedudukannya di dalam hukum dan pemerintahan itu dengan tidak ada kecualinya.

Hukum menetapkan apa yang harus dilakukan, mengatur mengenai segala sesuatu yang boleh dilakukan serta berbagai hal yang dilarang. Sasaran hukum yang hendak dituju bukan saja orang yang nyata-nyata berbuat melawan hukum, melainkan juga perbuatan hukum yang mungkin akan terjadi. Mengenai hal ini, kepada alat perlengkapan negara diberikan kewenangan untuk bertindak berdasarkan hukum. Sistem bekerjanya hukum yang demikian itu merupakan salah satu bentuk dari penegakan hukum.

Berkaitan dengan penegakan hukum, arus reformasi yang disponsori oleh mahasiswa Indonesia dan generasi muda negara Indonesia pada tahun 1998, telah menjatuhkan pemerintahan Orde Baru yang telah berkuasa lebih kurang 32 tahun. Gerakan reformasi ini melihat kelemahan pemerintahan Orde Baru yang telah menjadi rezim otoriter dengan dukungan militer, sehingga korupsi telah menjadi sangat endemik di kalangan birokrat (sipil dan militer), persekongkolan antara pemegang kuasa ekonomi untuk merlakukan perbuatan melawan hukum (kolusi) yang mendahulukan sanak saudara dan kerabat secara curang (nepotism), serta birokrasi yang sangat sentralistik yang menekan dari atas (top down), (Syahrin, 2009).

Keadaan yang terjadi pada masa Orde Baru tersebut, sangat sesuai dengan apa yang diungkapkan oleh Lord Acton yang menghubungkan antara korupsi dan kekuasaan. Acton menyatakan dalam (Djaja, 2008) bahwa, "power tends to ccorrupt, and absolute power tends corrupts absolutely”, yang maknanya adalah kekuasaan cenderung untuk korupsi dan kekuasaan yang absolut cenderung korupsi absolut.

Saat ini, di tengah upaya reformasi yang telah dan terus didengung-dengungkan, aspirasi masyarakat untuk memberantas korupsi dan berbagai bentuk penyimpangan lain semakin meningkat, karena dalam kenyataannya perbuatan korupsi telah menimbulkan kerugian negara yang sangat besar yang pada gilirannya dapat berdampak pada timbulnya krisis di berbagai bidang. Untuk itu, upaya pencegahan dan pemberantasan korupsi perlu 
semakin ditingkatkan dan diintensifkan dengan tetap menjunjung tinggi hak asasi manusia dan kepentingan masyarakat, (Djaja, 2008).

Dalam kenyataannya, korupsi bukan hanya terjadi di Indonesia, di belahan dunia yang lain pun tindak pidana korupsi akan selalu mendapatkan perhatian yang lebih khusus dibandingkan dengan tindak pidana lainnya. Bahkan Perserikatan Bangsa-Bangsa (PBB), PBB sebagai suatu organisasi bangsa-bangsa seluruh dunia telah memberikan perhatian khusus terhadap korupsi. Salah satu contohnya adalah dengan menetapkan tanggal 9 Desember sebagai Hari Anti Korupsi Sedunia. Tujuan penetapan ini tiada lain sebagai bentuk keseriusan untuk ikut serta memberantas korupsi di dunia, mengingat dampak negatif yang ditimbulkan oleh tindak pidana korupsi dapat mendistorsi berbagai kehidupan berbangsa dan bernegara dari suatu negara, bahkan juga terhadap kehidupan antar negara.

Hal senada juga disampaikan oleh Gunnar Myrdal (dalam Setyadi, 2008) yang menyatakan bahwa korupsi pada dasarnya tidak pernah membawa akibat yang positif, namun selalu mengakibatkan hal yang buruk, seperti:

a. Korupsi memantapkan dan memperbesar masalah-masalah yang menyangkut kurangnya hasrat untuk terjun di bidang usaha dan mengenai kurang tumbuhnya pasaran nasional

b. Korupsi mempertajam permasalahan masyarakat plural sedang bersamaan dengan itu kesatuan negara bertambah lemah. Juga karena turunnya martabat pemerintah, tendensi-tendensi itu membahayakan stabilitas politik.

c. Korupsi mengakibatkan turunnya disiplin nasional. Uang suap itu tidak hanya dapat memperlancar prosedur administrasi, tetapi biasanya juga berakibat adanya kesengajaan untuk memperlambat proses administrasi agar dengan demikian dapat menerima uang suap.

Tindak pidana korupsi merupakan masalah yang sangat serius, karena tindak pidana korupsi tidak hanya dapat membahayakan stabilitas dan keamanan negara beserta masyarakatnya, namun juga berdampak ke bidang politik, sehingga tidak dapat dipungkiri apabila nantinya korupsi bisa pula merusak nilai-nilai demokrasi serta moralitas bangsa karena akan berdampak membudayakannya tindak pidana korupsi tersebut. Hal tersebut sebagaimana tercantum dalam Preambule ke-4 United Nations Convention Against Corruption ( UNCAC), 2003, yang berbunyi:

"Convinced that corruption is no longer a local matter but transnational phenomenon that affects all societies anfd economics, making international cooperation to prevent and control it essentiall. (Meyakini, bahwa korupsi tidak lagi merupakan masalah lokal, melainkan suatu fenomena transnasional yang mempengaruhi seluruh masyarakat dan ekonomi yang mendorong kerjasama internasional untuk mencegah dan mengontrolnya secara essensial)” 
Data tentang prestasi korupsi Indonesia menurut Indonesia Corruption Watch (ICW) selama tahun 2006-2008, kerugian negara akibat tindak pidana korupsi mencapai Rp. 24 trilyun, dengan kerugian negara terbesar terjadi tahun 2006 dengan nilai sebesar Rp. 14,4 trilyun (Rohim, 2008). Bahkan lebih tragis lagi, Corruption Index Perception (Transpacy International) menempatkan Indonesia pada peringkat ke-5 negara terkorup dari 146 negara. Data ini tentu semakin menambah buruknya citra bangsa Indonesia setelah sebelumnya banyak pakar dalam negeri mengestimasi korupsi di Indonesia telah mengakibatkan kebocoran anggaran negara sebesar 30\% hingga 50\% yang menciptakan ekonomi berbiaya tinggi, (Nurdjana, 2005).

Banyak faktor yang menyebabkan orang melakukan korupsi. Salah satu faktor tersebut adalah kemiskinan. Menurut Jeremy Pope kemiskinan merupakan faktor penyebab korupsi, meskipun bukan satu-satunya (Rohim, 2008). Terjadinya korupsi menurut Badan Pengawasan Keuangan dan Pembangunan (BPKP) tahun 1997, lebih disebabkan oleh aspek individu pelaku korupsi seperti sikap tamak, moral dan iman yang lemah, sehingga tidak dapat menahan godaan hawa nafsu serta penghasilan kurang mencukupi kebutuhan hidup yang wajar.

Sedangkan Hamzah (dalam Rohim, 2008) yang kemudian mengulas korupsi dalam lingkup yang berkaitan dengan kekuasaan atau wewenang ataupun kedudukan, menyebutkan beberapa sebab terjadinya perbuatan korupsi antara lain:

a. Kurangnya gaji atau pendapatan pegawai negeri dibandingkan dengan kebutuhan yang makin hari semakin meningkat

b. Latar belakang kebudayaan atau kultur Indonesia yang merupakan sumber atau sebab meluasnya korupsi.

c. Beberapa pasal yang ada dalam KUHP dipandang kurang memadai untuk masyarakat Indonesia yang pejabat-pejabatnya cenderung melakukan penyalahgunaan kekuasaan untuk keuntungan diri sendiri.

d. Manajemen yang kurang baik dan kontrol yang kurang efektif dan efisien sering dipandang sebagai penyebab korupsi, sering dikatakan makin besar anggaran pembangunan, maka semakin besar pula kemungkinan terjadinya kebocoran.

Berbagai upaya telah dilakukan dalam usaha memberantas tindak pidana korupsi, baik yang bersifat preventif maupun yang bersifat represif. Bahkan peraturan perUndang-undangan korupsi sendiri telah mengalami beberapa kali perubahan. Pada waktu seluruh wilayah Indonesia masih dalam keadaan perang, atas dasar Undang-undang Nomor 74 Tahun 1957 jo. Undang-undang Nomor 79 Tahun 1957, dalam rangka pemberantasan korupsi telah diberlakukan Peraturan Penguasa Militer Nomor PRT/PM/011/1957 tentang Pemberantasan Korupsi, yang kemudian diganti dengan Peraturan Penguasa Perang Pusat Angkatan Darat 
Nomor PRT/PEERPU/013/1958 tentang Pengusutan, Penuntutan, dan Pemeriksaan Perbuatan Korupsi, Pidana dan Pemilikan Harta Benda, serta peraturan-peraturan pelaksanaannya dan selain itu juga dikeluarkan Peraturan Penguasa Perang Pusat/ Kepala Staf Angkatan Laut Tanggal 7 April 1958 Nomor Prt/Z/I/7 (Wiyono, 2008).

Akhirnya karena keadaan yang mendesak, di mana korupsi semakin merajalela sedangkan pengaturannya tidak jelas, maka atas dasar Pasal 96 ayat (1) Undang-undang Dasar Sementara 1950, dilakukanlah penggantian peraturan penguasa perang pusat dengan menetapkannya menjadi Peraturan Pemerintah Pemerintah Pengganti Undang-undang Nomor 24 Tahun 1960 tentang Pengusutan, Penuntutan, Dan Pemeriksaan Tindak Pidana Korupsi, yang kemudian atas dasar Undang-undang Nomor 1 Tahun 1960 menjadi Undang-undang Nomor 24 Prp Tahun 1960 tentang Pengusutan, Penuntutan, Dan Pemeriksaan Tindak Pidana Korupsi (Wiyono, 2008).

Namun sangat disayangkan, di dalam perjalanannya penerapan Undang-undang Nomor 24 Tahun 1960 ternyata masih belum mencapai hasil seperti yang diharapkan. Ini bisa dilihat dari angka korupsi yang bukannya semakin menurun, malah semakin meningkat. Hal ini kemudian berdampak dengan digantikannya pengaturan mengenai korupsi, seiring dengan diberlakukannya Undang-undang Nomor 3 Tahun 1971 tentang Pemberantasan Tindak Pidana Korupsi.

Berdasarkan berbagai pertimbangan, ternyata lebih dari dua dasawarsa berlaku, Undang-undang Nomor 24 Tahun 1960 tersebut sudah tidak sesuai lagi dengan perkembangan kebutuhan hukum dalam masyarakat. Apalagi semakin lama, praktik-praktik korupsi, kolusi, dan nepotisme mulai melibatkan para penyelenggara negara dengan para pengusaha. Oleh karena itu sudah sewajarnya jika kemudian Majelis Permusyawaratan Rakyat (MPR) sebagai lembaga tertinggi negara saat itu menetapkan Ketetapan MPR Nomor IX/MPR/1998 tentang Penyelenggaraan Negara yang Bersih dan Bebas Dari Korupsi, Kolusi dan Nepotisme, yang antara lain menetapkan agar diatur lebih lanjut dengan undang-undang tentang pemberantasan tindak pidana korupsi yang dilakukan dengan tegas, dengan melaksanakan secara konsisten Undang-undang tindak pidana korupsi.

Atas dasar Tap MPR Nomor IX/MPR/1998 ini, kemudian ditetapkan Undang-undang Nomor 31 Tahun 1999 tentang Pemberantasan Tindak Pidana Korupsi yang mulai berlaku tanggal 16 Agustus 1999. Sedangkan Undang-undang Nomor 3 Tahun 1971 tentang Pemberantasan Tindak Pidana Korupsi dinyatakan tidak berlaku lagi. Namun beberapa tahun kemudian diadakan perubahan terhadap Undang-undang tersebut dengan ditetapkannya 
Undang-undang Nomor 20 Tahun 2001 tentang Perubahan Atas Undang-undang Nomor 31 Tahun 1999. Alasan diadakan perubahan terhadap Undang-undang Nomor 31 Tahun 1999 dapat diketahui dari konsiderans butir b dan c Undang-undang Nomor 20 Tahun 2001, yaitu:

1. untuk lebih menjamin kepastian hukum;

2. menghindari keragaman penafsiran hukum;

3. memberikan perlindungan terhadap hak-hak sosial ekonomi masyarakat;

4. perlakuan secara adil dalam memberantas tindak pidana korupsi.

Tindak pidana korupsi sebagai suatu extra ordinary crime telah membawa dampak yang begitu besar terhadap suatu negara. Bagaimana tidak? Keuangan suatu negara yang semestinya dapat dipergunakan sebagaimana mestinya telah disalahgunakan oleh para koruptor untuk kepentingan pribadinya maupun golongan tertentu. Sebagai contoh negara Filipina yang dalam upaya pengembalian aset saja, membutuhkan waktu 18 tahun untuk menarik kembali dana sebesar USD 624 juta hasil penyelewengan uang negara oleh mantan Presiden Ferdinand Marcos di sebuah bank di Swiss. Dalam kasus Ferdinand Marcos pada tahun 1986, pemerintah Filipina telah membentuk lembaga khusus untuk mengembalikan aset yang telah dikorupsi Marcos, yaitu The Presidential Commision on Good Governance (PCGG) (Pohan, 2008). Aksi pertama PCGG yang dapat dicatat sebagai suatu keberhasilan PCGG adalah pada Maret 1986, atau lebih kurang sebulan setelah dibentuknya PCGG, di mana otoritas di Swiss telah membekukan aset yang dikuasai Marcos yang berada di Swiss.

Pengembalian aset Marcos tidak selamanya berjalan mulus, PCGG juga mengalami berbagai kendala dalam pengembalian aset. Kegagalan pertama, yaitu berkaitan dengan ditolaknya permohonan bantuan hukum (mutual legal assistance) kepada Swiss Police Departement. Sangat mungkin hal ini lebih disebabkan persoalan teknis yuridis. Keadaankeadaan semacam ini seharusnya dapat diminimalisir atau dihindari dengan menggunakan jasa lawyer yang handal seperti dalam kasus Sani Abacha (presiden Nigeria), yang mana telah menggunakan jasa pengacara setempat untuk membantu melakukan upaya-upaya hukum dalam rangka pengembalian aset dari Swiss, (Pohan, 2008).

Kegagalan kedua, ternyata PCGG baru melakukan gugatan perdata untuk mengembalikan aset yang dikuasai Marcos pada Desember 1991, padahal lembaga tersebut telah dibentuk 6 (enam) tahun sebelumnya. Hal ini disebabkan karena pemerintah Filipina harus menunggu dokumen bank yang berkaitan dengan deposit Marcos di Swiss. Pengiriman dokumen tersebut mengalami hambatan, karena menunggu adanya putusan pengadilan di Swiss yang mengizinkan pengiriman dokumen tersebut. Putusan tersebut baru diperoleh pada 
tanggal 20 Desember 1990, yang mana Swiss Federal Supreme Court mengizinkan transfer dokumen tersebut kepada pemerintah Filipina. Pengalaman ini dapat dihindari apabila didukung oleh hukum pembuktian yang lebih menguntungkan, misalnya ada beban pembuktian terbalik, sehingga pihak PCGG tidak perlu menunggu dokumen perbankan dari otoritas di Swiss.

Keterlambatan upaya pengembalian aset berikutnya berada pada sistem hukum di Filipina. Diperlukan waktu kurang lebih 6 tahun sejak transfer dilakukan ke escrow account di Philippine National Bank (PNB), The Phillipine Supreme Court baru dapat memutuskan secara final suatu perintah perampasan dan atau penyitaan terhadap semua deposit atas nama Ferdinand Marcos di Swiss.

Contoh lainnya adalah Nigeria yang memenangkan kasus pengembalian dana sebesar USD 500 juta dari mantan diktator Sani Abacha. Setelah lima tahun berjuang di pengadilan, akhirnya Nigeria berhasil menarik dana tersebut dari sebuah bank di Swiss. Padahal, Sani diyakini telah menggerogoti uang negara lebih dari USD 5 miliar selama lima tahun. Sementara itu, sekitar 25\% produk domestik bruto (GDP) negara-negara di Afrika setiap tahunnya dilaporkan raib akibat dikorupsi, yang jumlah totalnya mencapai angka USD 148 miliar.

Sumatera Barat, sebagai salah satu propinsi di Indonesia, juga tidak luput dari persoalan korupsi. Dimulai dari adanya istilah korupsi berjamaah yang melibatkan para anggota Dewan Perwakilan Rakyat Daerah (DPRD) Sumatera Barat Periode 1999-2004. Setelah itu, sampai tahun 2009, di Sumatera Barat telah terjadi 106 kasus korupsi yang diperkirakan negara mengalami kerugian sebesar Rp. 114,198 Milyar dan telah melibatkan berbagai kalangan. Dalam konferensi pers beberapa waktu lalu, Kepala Kejaksan Tingi Sumatera Barat dalam acara tersebut menyampaikan bahwa Kejaksaan Tinggi Sumatera Barat sampai tanggal 10 Februari 2011 dari 51 kasus yang ditangani telah berhasil menyelamatkan keuangan negara sebesar Rp. 2.975.460.000.- dari kerugian negara sebesar Rp. 29.710.653.690.- Bahkan, dalam kasus proyek PLTU Teluk Sirih, diperkirakan potensi kerugian negara mencapai Rp. 3 Milyar dan saat ini tim penyidik sudah menyelamatkan uang negara sebesar Rp. 1,1 Milyar (website Kejaksaan Tinggi Sumatera Barat, diakses Tanggal 14 Januari 2010)

Namun dari berbagai kasus yang terjadi, didominasi dari lembaga eksekutif. Kasus korupsi yang dilakukan dari lembaga ekskutif (pemerintahan) sebanyak 44 ( empat puluh empat) kasus, dari lembaga legislatif berjumlah 3 (tiga) kasus, sedangkan dari Badan Umum 
Milik Negara (BUMN) ditemukan kasus korupsi sebanyak 3 (tiga) kasus dan Badan Usaha Milik Daerah (BUMD) sebanyak 2 (dua) kasus. Sementara yang dilakukan dari pihak swasta yang sebanyak 11 (sebalas) kasus. Selain itu, selama tahun 2010 kasus korupsi yang masuk di meja Kejaksaan Tinggi Sumatera Barat sebanyak 84 (delapan puluhempat) kasus. Dari jumlah kasus tersebut, sebanyak 45 kasus telah dilakukan penyidikan olek kejaksaan-kejaksaan diseluruh Sumatera Barat.

Dalam penyidikan kasus korupsi, salah satu tujuannya adalah penyelamatan kerugian keuangan negara. Sampai saat ini, tindak pidana korupsi masih merupakan salah satu tindak pidana yang berbahaya dan sangat merugikan. Sehingga sejalan dengan itu, pemerintah selalu berupaya untuk menunjukan keseriusan untuk memberantasnya. Salah satu bentuknya adalah dengan mewujudkan keseriusan pemerintah dalam upaya bagaimana mengembalikan keuangan negara yang telah hilang karena dikorupsi. Untuk itu, akhirnya pemerintah mengeluarkan berbagai kebijakan untuk menunjukan keseriusan dalam memberantas korupsi. Selain itu berbagai macam ketentuan-ketentuan di atas, Presiden Susilo Bambang Yudhoyono juga telah mengeluarkan Instruksi Presiden Nomor 5 Tahun 2004 tentang percepatan pemberantasan korupsi, yang menginstruksikan secara khusus kepada Jaksa Agung dan Kapolri untuk:

1. Mengoptimalkan upaya-upaya penyidikan/ penuntutan terhadap tindak pidana korupsi untuk menghukum pelaku dan menyelamatkan uang negara;

2. Mencegah dann memberikasn sanksi tegas terhadap penyalahgunaan wewenang yang dilakukan oleh jaksa (penuntut umum) atau anggota Polri dalam rangka penegakan hukum;

3. Meningkatkan kerjasama antara kejaksaan dengan kepolisian negara RI, selain dengan BPKP, PPATK, dan institusi negara yang terkait dengan upaya penegakan hukum dan pengambilan kerugian keuangan negara akibat tindak pidana korupsi.

Pada poin (3) di atas diungkapkan begitu pentingnya upaya pengembalian aset-aset atau keuangan negara dari para pelaku tindak pidana korupsi. Hal itu wajar mengingat berapa besar keuangan negara yang seharusnya dapat mewujudkan pembangunan untuk kesejahteraan rakyat yang pada akhirnya telah diselewengkan. Makna yang sama dalam hal pengembalian aset-aset negara juga tercantum dalam konsideran menimbang huruf $b$ Undangundang Nomor 7 Tahun 2006, tentang Pengesahan United Nations Convention Against Corruption (UNCAC), 2003, yang berbunyi:

Bahwa tindak pidana korupsi tidak lagi merupakan masalah lokal, akan tetapi merupakan fenomena transnasional yang mempengaruhi seluruh masyarakat dan perekonomian sehingga penting adanya kerjasama internasional untuk pencegahan dan pemberantasannya termasuk pemulihan atau pengembalian aset-aset hasil tindak pidana korupsi 
Selain itu pengembalian aset ini, juga tercantum pada alinea pertama Penjelasan Umum Undang-undang Nomor 7 Tahun 2006 Tentang Pengesahan UNCAC 2003, yaitu sebagai berikut:

Tindak pidana korupsi merupakan ancaman terhadap prinsip-prinsip demokrasi, yang menjunjung tinggi transparansi, akuntabilitas, dan integritas, serta keamanan dan stabilitas bangsa Indonesia. Oleh karena korupsi merupakan tindak pidana yang berifat sistemik dan merugikan pembangunan berkelanjutan sehingga memerlukan langkah-langkah pencegahan tingkat nasional maupun tingkat internasional. Dalam melaksanakan pencegahan dan pemberantasan tindak pidana korupsi yang efisien dan efektif diperlukan dukungan manajemen tata pemerintahan yang baik dan kerja sama internasional, termasuk pengembalian ast-aset yang berasal dari tindak pidana korupsi

Pengembalian aset-aset atau dapat dikatakan dengan pengembalian keuangan negara dari hasil tindak pidana korupsi menarik untuk dicermati. Dalam Pasal 4 Undang-undang Nomor 31 Tahun 1999, dijelaskan bahwa pengembalian kerugian negara atau perekonomian negara tidak akan menghapuskan pidana pelaku tindak pidana sebagaimana dimaksud dalam Pasal 2 dan Pasal 3. Meskipun begitu dalam Penjelasan Pasal 4 disebutkan bahwa pengembalian keuangan atau perekonomian negara merupakan salah satu faktor yang meringankan pidana yang dapat dijatuhkan kepada pelaku tindak pidana korupsi. Namun pertanyaan yang timbul adalah bagaimana proses pelaksanaan, upaya-upaya serta hambatanhambatan yang ditemui dalam suatu pengembalian kerugian keuangan negara tersebut.

\section{PEMBAHASAN}

\section{Pelaksanaan Pengembalian Kerugian Negara Dalam Tindak Pidana Korupsi di}

\section{Kejaksaan Negeri Sumatera Barat}

Berbicara mengenai pengembalian kerugian keuangan negara, berarti kita harus membahas berapa kerugian negara yang ditimbulkan akibat tindak pidana korupsi sebagaimana data yang telah diuraikan di atas. Dari jumlah kasus dan jumlah kerugian keuangan negara yang dilakukan oleh Penyidik Kejaksaan Tinggi Sumatera Barat hinga saat ini, baru 4 (empat) kasus yang sudah mendapatkan putusan berkekuatan hukum tetap (incraht). Walaupun dalam tahap penyidikan tidak dilakukan penyitaan terhadap asset-asset dari tersangka ( sebagaimana data di atas), namun, Kejaksaan Tinggi Sumatera Barat, sebagai salah satu istitusi penyidikan dalam tindak pidana korupsi, selalu berupaya bagaimana caranya agar semua kerugian negara yang telah ditimbulkan, dapat dikembalikan pada negara demi tuntasnya suatu proses peradilan pidana dalam tindak pidana korupsi. Dibawah ini akan 
diuraikan data putusan hakim yang telah mempunyai kekuatan hukum tetap dalam tindak pidana korupsi yang dituntut oleh Kejaksaan Tinggi Sumatera Barat.

Table 1. Pidana Uang Pengganti Yang Telah Mempunyai Kekuatan Hukum Tetap (Inkracht) Dalam Tindak Pidana Korupsi periode Januari s/d Desember 2010

\begin{tabular}{|c|c|c|c|c|}
\hline No & $\begin{array}{c}\text { Kejaksaan } \\
\text { Negeri }\end{array}$ & Nama Terdakwa & Uang Pengganti & Keterangan \\
\hline 1 & 2 & 3 & 4 & 5 \\
\hline 1. & Padang & $\begin{array}{l}\text { 1. Ir. Syhil Noer, } \\
\text { dkk } \\
\text { 2. Musfa Yendi, dkk } \\
\text { 3. Syamsurizal Dipl } \\
\text { M.M }\end{array}$ & $\begin{array}{l}\text { Rp. } \quad 70.000 .000,- \\
\text { Rp. } 405.612 .049,- \\
\text { Rp. } \quad 216.480 .000 .-\end{array}$ & $\begin{array}{l}\text { Sudah } \\
\text { dieksekusi. } \\
\text { belum } \\
\text { dieksekusi. } \\
\text { belum } \\
\text { dieksekusi. }\end{array}$ \\
\hline 2. & Tua Pejat & $\begin{array}{l}\text { 1. Drs. Ali Arifin. } \\
\text { 2. Afner } \\
\text { Ambarita, SH }\end{array}$ & $\begin{array}{l}\text { Rp. } 508.975 .813,- \\
\text { Rp. } \quad 55.000 .000,-\end{array}$ & $\begin{array}{l}\text { belum } \\
\text { dieksekusi. } \\
\text { belum } \\
\text { dieksekusi. }\end{array}$ \\
\hline 3. & Payakumbuh & Ir. Sulaiman & Rp. $\quad 44.000 .000,-$ & $\begin{array}{l}\text { belum } \\
\text { dieksekusi. }\end{array}$ \\
\hline 4. & $\begin{array}{l}\text { Lubuk } \\
\text { Basung }\end{array}$ & M. Kalif Indra. & 95.603.500,- & $\begin{array}{l}\text { belum } \\
\text { dieksekusi. }\end{array}$ \\
\hline \multicolumn{3}{|c|}{ JUMLAH } & Rp. 1.395.671.362 & $\begin{array}{l}\text { Yang telah } \\
\text { dieksekusi } \\
\text { berjumlah } \\
70 \text { juta } \\
\text { rupiah }\end{array}$ \\
\hline
\end{tabular}


Korupsi sebagai suatu ekstra ordinary crime menyebabkan kerugian negara yang tidak sedikit, kerugian negara yang dimaksud dapat dilakukan upaya pengembalian oleh pihak kejaksaan dari mulai proses penyidikan, antara lain dengan melalui penyitaan dan perampasan. Khusus untuk kasus yang ditangani langsung oleh Kejaksaan Tinggi Sumatera Barat, berdasarkan putusan yang telah mempunyai hukum tetap (inkraht) dalam kurun waktu Januari sampai Desember 2010, sebagaimana tabel di atas, jumlah pidana uang penganti sebesar Rp. 1.395.671.362.-. Namun pidana uang pengganti tersebut yang berhasil dieksekusi baru sebesar Rp 70.000.000,

Namun permasalahan dalam pengembalian aset tindak pidana korupsi, besarnya kerugian negara yang ditimbulkan, tidak sesuai dengan apa yang telah dilakukan pihak kejaksaan dalam upaya untuk mengembalikan kerugian negara tersebut. Hal tersebut sangat jauh dari apa yang diharapkan dalam semangat pemberantasan korupsi. Hal ini menunjukan betapa lemahnya kejaksaan sebagai penegak hukum dalam upaya mengembalikan uang atau asset negara yang telah di korupsi.

Selama ini pihak kejaksaan dalam upaya mengembaikan kerugian negara, kurang agresif dan proaktif. Lembaga tersebut lebih dominan untuk melakukan upaya penyitaan dan atau perampasan setelah adanya putusan pengadilan yang telah mempunyai kekuatan hukum tatap. Jarang dilakukan upaya-upaya paksa atau pengembalian kerugian negara dari mulai proses awal penyidikan perkara. Seharusnya pada saat penyidikanpun, pihak kejaksaan harus lebih bekerja ekstra keras dalam upaya mencari dan menemukan harta dari kekayaan tersangka yang berkaitan langsung dengan tindak pidana. Penyidik dapat melakukan penyitaan terhadap mobil, rumah dan bahkan dana dari rekening tersangka, yang nantinya pada saat di persidangan tentunya akan menjadi bukti terhadap kasus yang ditangani. Dalam pelaksanaan pengembalian kerugian keuangan negara atau perekonomian negara dalam tindak pidana korupsi, pihak kejaksaan selaku eksekutor terhadap putusan pengadilan yang telah mempunyai kekuatan hukum tetap (inkracht) dalam wilayah hukumnya lebih didasarkan pada Pasal 18 Undang-undang Nomor 31 Tahun 1999 tentang pemberantasan tindak pidana korupsi (Wawancara dengan Kasi Upaya Hukum dan Eksekusi (UHEK) Zulkifli, SH , Kejaksaan Tinggi Sumatera Barat, 17 Desember 2010 di Padang)

Pembayaran uang pengganti merupakan pidana tambahan, namun saat ini, usaha untuk mengembalikan ase-aset negara khususnya uang yang telah dikorupsi oleh pelaku semakin gencar dilakukan. Bahkan upaya tersebut dapat dimulai saat dilakukannya penyidikan tindak pidana korupsi. Dalam tahap tersebut, pihak kejaksaan dapat melakukan penyitaan aset-aset 
milik terdakwa yang diduga barasal dari hasil tindak pidana. Namun, di Kejaksaan Tinggi Sumatera Barat, dalam upaya pengembalian kerugian negara, langkah itu lebih dititikberatkan dilakukan setelah adanya putusan pengadilan yang telah inkraht. Meskipun jaksa tidak dapat memperpanjang tentang waktu pembayaran uang pengganti kerugian negara, tetapi perumusan dari ketentuan yang terdapat dalam Pasal 18 ayat (2) “ paling lama dalam waktu 1 (satu) bulan”, maka jaksa masih dapat menentukan tahap-tahap pembayaran uang pengganti, tetapi dengan syarat tahap-tahap tersebut tidak melebihi tenggang waktu 1(satu) bulan.

Dalam implementasi/penerapan pengembalian kerugian keuangan negara atau perekonomian negara terhadap kasus tindak pidana korupsi yang dilakukan oleh terdakwa, jika pengadilan sudah menjatuhkan putusannya menggenai pembayaran uang pengganti tersebut sebagaimana dimaksud dalam Pasal 18 ayat (1) huruf b, kepada terpidana diberi tenggang waktu untuk membayar uang pengganti seperti yang ditentukan dalam Pasal 18 ayat (2) yaitu "paling lama dalam waktu 1 (satu) bulan sesudah putusan pengadilan yang telah memperoleh kekuatan hukum tetap”. Terhadap tenggang waktu tersebut, jaksa sebagai pelaksana dari putusan pengadilan , tidak dapat memperpanjang tenggang waktu pembayaran uang pengganti kerugian negara, tidak seperti halnya jaksa dapat memperpanjang waktu pembayaran denda, yaitu yang ditentukan dalam Pasal 273 ayat (2) KUHAP, karena pembayaran uang pengganti denda berbeda dengan pembayaran denda. Akan tetapi dalam prakteknya tidak sesuai dengan teori-teori atau aturan-aturan di atas tentang tenggang waktu pengembalian kerugian negara akibat tindak pidana korupsi, karena demi dikembalikannya kerugian keuangan negara oleh terpidana, terpidana sendiri dalam membayar dapat melakukan penyicilan pembayaran dalam jangka beberapa tahun sesuai perjanjian dengan pihak eksekutor. Dalam hal ini terpidana memang benar-benar tidak membayar sekaligus kerugian keuangan negara yang dilakukannya. (Wawancara dengan Kasi Upaya Hukum dan Eksekusi (UHEK) Zulkifli, SH , Kejaksaan Tinggi Sumatera Barat, 17 Desember 2010 di Padang). Jika tenggang waktu untuk pembayaran uang pengganti sudah lewat dan ternyata terpidana tidak membayar uang pengganti, tindak lanjutnya adalah seperti yang dilakukan dalam Pasal 18 ayat (2), yaitu “...maka harta bendanya dapat disita oleh jaksa dan dilelang untuk menutupi uang pengganti tersebut”.

Harta benda yang dimaksud adalah harta benda kepunyaan terpidana yang bukan merupakan harta benda hasil dari tindak pidana korupsi dan/atau harta benda kepunyaan terpidana yang bukan dipergunakan untuk melakukan tindak pidana korupsi, karena jika memang terbukti disidang pengadilan, bahwa harta benda kepunyaan terpidana tersebut 
merupakan harta benda hasil dari tindak pidana korupsi dan/atau dipergunakan untuk melakukan tindak pidana korupsi, maka pengadilan sudah tentu akan menjatuhkan pidana tambahan berupa perampasan barang-barang sebagaimana dimaksud dalam Pasal 39 ayat (1) KUHAP juncto Pasal 18 ayat (1) huruf b, sehingga jaksa tidak perlu sampai melakukan penyitaan terhadap barang-barang yang dimaksud dan dilelang untuk menutupi kerugian negara tersebut.

Penyitaan dan pelelangan terhadap harta benda kepunyaan terpidana dilakukan oleh jaksa eksekutor jika ternyata terpidana belum atau tidak membayar kerugian negara yang jumlahnya seperti yang dimuat pada putusan pengadilan dalam tenggang waktu yang telah ditentukan. Ketentuan pembayaran kerugian negara tersebut seharusnya telah dibayar dalam tenggang waktu 1 (satu) bulan setelah putusan hakim yang telah mempunyai kekuatan hukum tetap. Namun hal tersebut tidak terlaksana meski telah diupayakan oleh pihak kejaksaan selaku eksekutor putusan hakim dalam hal pengambilan uang pengganti tindak pidana korupsi dengan melakukan koordinasi dengan pihak keluarga dan pemerintah setempat serta instansi instansi terkait.

Penyitaan terhadap harta benda kepunyaan terpidana yang tidak melakukan pembayaran uang pengganti tidak perlu meminta izin terlebih dahulu dari ketua Pengadilan Negeri setempat. Namun sesudah melakukan penyitaan jaksa eksekutor segera melaporkan kepada ketua Pengadilan Negeri setempat untuk mendapatkan persetujuan, karena penyitaan ini dilakukan bukan dalam rangka penyidikan, tetapi dalam rangka pelaksanaan putusan pengadilan (Surat Edaran Mahkamah Agung RI Nomor 4 tahun 1988.)

Jaksa dalam melakukan penyitaan terhadap harta benda kepunyaan tersebut harus dapat memperkirakan harga asli yang disita, yang jika dilelang sudah dapat menutupi jumlah kerugian negara seperti yang dimuat dalam putusan pengadilan. Diharapkan jangan sampai terjadi beberapa kali dilakukan penyitaan harta benda kepunyaan terpidana, karena salah memperkirakan harta dari harta benda yang disita, yang setelah dilelang ternyata tidak dapat menutupi jumlah uang pengganti yang dibayar.

Dalam wawancara yang dilakukan dengan pihak kejaksaan, ada beberapa proses atau tahap dalam pengembalian kerugian negara. Menurut Zulkifli, SH, bahwa selama ini pihak kejaksaan telah berupaya semaksimal mungkin berupaya dari mulai tahap penyidikan sampai ke tahap eksekusi, langkah-langkah yang ditempuh antara lain (wawancara dengan Kasi Upaya Hukum dan Eksekusi tanggal 17 Desember 2010 di Padang). 


\section{Pada Tahap Penyidikan.}

Dalam rangka penyelamatan keuangan dan perekonomian negara akibat tindak pidana korupsi, Jaksa penyidik semenjak dimulainya penyidikan dapat melakukan penyitaan terhadap harta benda tersangka, isteri/suami, anak dan setiap orang atau badan yang mempunyai hubungan dengan perkara tersangka.misalnya mobil, rumah dan bahkan rumah tersangka.

\section{Pada Tahap Penuntutan.}

Pada tahap penuntutan, jaksa/penuntut umum dalam tuntutan pidananya wajib meminta kepada hakim agar menjatuhkan pidana tambahan berupa pembayaran uang penggati pokok, dan menyatakan merampas barang-barang yang disita dalam tahap penyidikan. Nilai dari keseluruhan barang-barang yang dimohonkan untuk dirampas dan jumlah tuntutan pembayaran uang pengganti, adalah sebanyak-banyaknya sama dengan harta benda yang diperoleh dari korupsi.

Pada tahap eksekusi

a. Dalam rangka melaksanakan putusan hakim, jika pembayaran uang pengganti belum mencukupi, jaksa melakukan penyitaan terhadap harta benda lainnya dari terpidana tanpa melakukan campur tangan pihak pengadilan dalam bentuk izin penyitaan yang dituangkan dalam penetapan dan lain-lain.

b. Seandainya dengan pelaksanaan kali ini, jumlah barang-barang yang dimiliki oleh terpidana juga tidak mencukupi lagi, kekurangan yang masih ada, agar ditagih melalui gugatan perdata.

c. Untuk perkara-perkara yang berdasarkan putusan Hakim telah memperoleh kekuatan hukum tetap, namun hakim tidak menetapkan ketentuan dalam Pasal 18 ayat 1 (satu) huruf b Undang- Undang Nomor 31 Tahun 1999, agar diusahakan pemberian kuasa dari instansi yang bersangkutan kepada Jaksa sebagai yang menerima kuasa (Penasihat Hukum) untuk mengajukan gugatan perdata mewakili negara/instansi yang bersangkutan pada pengadilan yang berwenang.

1. Dalam hal terpidana meninggal dunia, maka untuk pembayaran uang pengganti berdasarkan putusan Hakim yang telah memperoleh kekuatan hukum tetap, Jaksa melakukan penyitaan terhadap harta benda yang ditinggalkan terpidana kepada ahli warisnya, yang sebanyak banyaknya sama dengan yang diperoleh dari korupsi.

2. Dalam hal perolehan barang-barang hasil korupsi yang ada pada orang lain sebagian atau seluruhnya, maka memenuhi pembayaran uang pengganti berdasarkan putusan hakim yang telah memperoleh kekuasaan hukum tetap, Jaksa mengusahan pengembalian barang-barang tersebut antara lain berupa pembayaran harta yang jumlahnya sama dengan nilai barang- barang itu. Jika upaya-upaya tersebut tidak membawa hasil, Jaksa mengajukan gugatan perdata terhadap pihak ketiga yang dengan sengaja tidak bersedia menyerahkan atau memindah tangankan barangbarang tersebut 
Berbicara mengenai penegembalian kerugian keuangan negara di Kejaksaan Tinggi Sumatera Barat, agak berbeda dengan apa yang seperti diungkapkan di atas. Disini, penegembalian kerugian keuangan negara lebih ditekankan pada putusan hakim yang telah mempunyai kekuatan hukum tetap, walaupun pada suatu waktu diadakan suatu upaya pencarian aset-aset atupun harta-harta dari tersangka, dan selanjutnya akan melakukan upayaupaya paksa yang dilakukan oleh opihak kejaksaan. Pasal 2 dan Pasal 3 Undang-undang Nomor 31 Tahun 1999, menyebutkan bahwa salah satu unsur dari tindak pidana korupsi adalah dapat merugikan keuangan negara.

Namun pengembalian kerugian keuangan negara atau perekonomian negara tidak akan menghapuskan pidana para pelaku tindak pidana korupsi. Hal ini sebagaimana yang termaktub di dalam Pasal 4 UU Tindak Pidana Korupsi, sehingga bila Pasal 2 dan Pasal 3 telah memenuhi unsur/elemen pasal yang dimaksud, maka pengembalian kerugian keuangan negara atau perekonomian negara, tidak akan menghapuskan pidana terhadap pelaku tindak pidana korupsi tersebut.

Jika melihat pada normanya, maka pengembalian kerugian keuangan negara ini hanyalah salah satu alasan meringankan hukuman (clementie). Namun sebelum berlakunya Undang-undang Tindak Pidana Korupsi yang Nomor 31 Tahun 1999, ada begitu banyak kasus korupsi yang akhirnya tidak berlanjut ke ranah hukum. Hal ini disebabkan karena adanya pemahaman bahwa dengan dilakukannya pengembalian keuangan maupun perekonomian dikembalikan, maka tindak pidananya menjadi hilang. Contohnya saja pada kasus dugaan korupsi yang dilakukan oleh mantan Direktur Utama Pertamina, mantan Menteri Perhubungan ataupun kasus-kasus pejabat tinggi lainnya yang permasalahannya dianggap telah selesai setelah kasusnya diambil alih oleh Presiden.

Keharusan untuk melakukan pembayaran uang pengganti tersebut dilakukan untuk mengembalikan keuangan negara yang telah dikorupsi oleh para koruptor. Tuntutan jaksa terhadap pengembalian keuangan negara dan perekonomian negara ini sebenarnya sejalan dengan putusan hakim, yang dalam putusannya seringkali memerintahkan agar terdakwa membayar kerugian negara yang jumlahnya sebanyak-banyaknya sama dengan jumlah kerugian negara ataupun perekonomian negara yang telah dikorupsinya (Data Tuntutan dan Putusan Perkara Tindak Pidana Korupsi di Sumatera Barat). Masalah yang kemudian muncul adalah, mengenai perbedaan besaran tuntutan jaksa terhadap pengembalian keuangan negara dengan besaran yang harus dibayarkan oleh terdakwa sebagaimana yang telah diputuskan oleh hakim. Hal ini terjadi karena terjadi perbedaan cara tafsir antara jaksa dalam penyidikan dan 
Rustam: Pelaksanaan Pengembalian Kerugian Keuangan Negara...

penuntutan dengan cara tafsir hakim di sidang pengadilan yang kemudian akan mempengaruhi putusan hakim dalam hal tuntutan pembayaran uang pengganti dalam mengadili kasus tindak pidana korupsi (Hasil wawancara dengan Zulkifli, SH. Kasi Upaya Hukum dan Eksekusi (UHEK), Kejaksaan Tinggi Sumatrera Barat, 18 April 2010 di Padang)

Jika melihat pada rumusan yang ada di dalam pasal 18 ayat (1) huruf a, maka cara menghitung jumlah kerugian keuangan negara ataupun perekonomian negara ini adalah dengan menyamakan jumlahnya yang harus diganti ataupun dibayarkan dengan jumlah kerugian yang dialami negara akibat tindak pidana korupsi yang dilakukannya. Hal ini dapat diberlakukan apabila sejak dilakukannya tindak pidana korupsi sampai pengadilan menjatuhkan putusan, nilai mata uang tetap stabil. Namun apabila terjadi kemerosotan nilai mata uang sejak dilakukannya tindak pidana sampai dengan pengadilan menjatuhkan putusan, maka jumlah yang harus dibayarkan perlu diperhitungkan kembali.

Menurut Kasi Upaya Hukum dan Eksukusi (UHEK) Kejati Sumbar mengatakan bahawa untuk dapat melaksanakan fatwa tersebut, maka diberikanlah petunjuk sebagai berikut:

1. Didalam perkara tindak pidana korupsi dalam rangka menyelamatkan kembali keuangan negara, maka terhadap terdakwa selain dituntut dengan pidana pokok (pidana penjara dan denda) agar dituntut juga dengan pidana tambahan membayar uang pengganti, kecuali bila mana seluruh kerugian negara akan ditutupi kembali dengan tuntutan perampasan barang bukti yang dalam tingkat penyidikan telah disita ataupun disetorkannya uang ke kas negara senilai jumlah kerugian

2. Jumlah pembayaran uang pengganti dalam ketentuan disebutkan "sebanyakbanyaknya sama dengan harta benda yang diperoleh dari korupsi, namun karena kesulitan untuk membuktikan adanya harta kekayaan terdakwa yang diperoleh dari korupsi, maka ketentuan tersebut hendaknya ditafsirkan bahwa pembayaran uang pengganti adalah sebesar kerugian negara yang ditimbulkan oleh perbuatan terdakwa.

3. Apabila dalam perkara tindak pidana korupsi terdiri atas beberapa orang terdakwa, maka tuntutan pembayaran uang pengganti yang dibebankan kepada masingmasing terdakwa sebesar yang dinikmati oleh masing-masing terdakwa dalam perkara yang bersangkutan. Dan untuk itu, hendaknya dari awal telah diperhitungkan jumlah terdakwa yang diajukan ke pengadilan yang kemudian diajukan menjadi beberapa berkas perkara, sehingga tuntutan pembayaran kerugian keuangan negara terhadap semua terdakwa tidak akan melebihi jumlah kerugian negara.

Berdasarkan Fatwa Kejaksaan Agung diatas, diharapkan untuk ke depannya terjadi penyeragaman didalam praktik pengembalian keuangan negara yang diakibatkan dari tindak pidana korupsi. Karena dengan pengembalian keuangan negara inilah, kerugian keuangan 
negara dapat dikembalikan oleh orang-orang yang telah memakai uang negara secara melawan hukum.

Dalam hubungannya dengan teori yang digunakan dalam penulisan ini, yakni teori penegakan hukum dan teori pemidanaan berkaitan dengan pengembalian kerugian keuangan negara dapat dikemukakan sebagai berikut. Dilihat dari sisi penegakan hukum, menurut Satjipto Rahardjo penegakan hukum berarti suatu proses untuk mewujudkan keinginankeinginan hukum menjadi kenyataan. Salah satu keinginan hukum dari peraturan perundangundangan pemberantasan tindak pidana korupsi adalah pengembalian kerugian keuangan negara. Bentuk pengembalian kerugian keuangan negara dikonkritkan dalam bentuk pidana uang pengganti sebagai salah satu pidana yang dijatuhkan terhadap pelaku tindak pidana korupsi. Adapun jumlah kerugian keuangan negara dalam tahap penyidikan sesuai data Kejaksaan Tinggi Sumatera Barat tahun 2010 berjumlah lebih 12 milyar dan tidak sedikitpun yang berhasil diselamatkan. Sementara dari putusan pengadilan yang telah inkracht, upaya penyelamatan terhadap keuangan negara kurang begitu memuaskan. Dalam tahun 2010 jumlah kerugian negara yang telah berhasil dieksekusi hanya Rp. 70.000.000,- (Tujuh Puluh Juta Rupiah).

Dengan demikian, dari sisi penegakan hukum, upaya pengembalian kerugian keuangan negara melalui proses penegakan hukum ini tidak berhasil secara maksimal. Hal ini dikarenakan nilai kerugian negara yang berhasil dikembalikan kepada negara jauh lebih kecil dibanding dengan kerugian negara yang ditimbulkan oleh tindak korupsi. Penegakan hukum tindak pidana korupsi di sumatera barat masih lemah. Sebagai mana yang dikemukakan oleh Soerdjono Soekanto, bahwa upaya penegakan hukum dipengaruhi oleh factor hukumnya, factor penegak hukum, factor sarana dan fasilitas penegakan hukum, factor masyarakat dan factor kebudayaan. Maka kelemahan penegakan hukum tindak pidana korupsi dalam hal pengembalian kerugian keuangan negara dipengaruhi juga oleh kelima factor tersebut. Kelemahan ini terlihat terutama dari sisi hukumnya, yakni tidak adanya pengaturan khusus tentang pengembalian kerugian keuangan negara (asset recovery). Dan dari sisi penegak hukum dipengaruhi oleh lemahnya mental dan sumber daya manusia serta politicalwill lembaga penegak hukum.

Dilihat dari teori pemidanaan, yang memiliki dua aspek yakni absolut (menekankan pembalasan) dan relatif (menekankan pencegahan). Pembayaran uang pengganti merupakan pidana tambahan dari ancaman pidana terhadap tindak pidana korupsi. Dengan adanya pidana pembayaran uang pengganti, pengembalian kerugian keuangan negara jelas merupakan salah 
satu tujuan penegakan hukum pidana korupsi. Dari sisi pemidanaan, pidana pembayaran uang pengganti mesti dilaksanakan sebagai pembalasan terhadap perbuatan melawan hukum dari tindak pidana korupsi. Dari jumlah pengembalian kerugian keuangan negara yang telah dilakukan oleh Kejaksaan Tinggi Sumatera Barat, menunjukan bahwa tujuan pemidanaan yang diharapkan sebagai pembalasan tidak berhasil secara maksimal. Hal ini dikarenakan pidana uang pengganti yang dijatuhkan dalam putusan hakim yang telah inkracht tidak sebanding dengan eksekusi yang dilakukan oleh jaksa eksekutor.

Seseorang yang melakukan kejahatan korupsi, maka disitu ada kepentingan hukum yang dilanggar. Salah satunya adalah mengenai kerugian negara yang menyangkut kepentingan masyarakat dan bahkan negara. Akibat yang timbul adalah tiada lain berupa suatu penderitaan baik pisik maupun psikis, ialah berupa perasaan tidak senang, sakit hati, amarah, tidak puas, dan terganggunya ketenteraman batin. Perasaan itu bukan tanpa sebab, masyarakat menganggap bahwa negara relah mengalami kerugian akibat pelaku tindak pidana korupsi. Untuk memuaskan dan atau menghilangkan penderitaan seperti ini, kepada pelaku harus diberikan pembalasan yang setimpal. Pelaku harus mengembalikan kerugian negara yang telah ditimbulkannya, yaitu dengan adanya upaya pengembalian aset yang dilakukan oleh pihak kejaksaan sebagai salah satu penegak hukum.

Dari uraian tersebut, baik dilihat dari sisi penegakan hukum maupun tujuan pemidanaan, maka upaya pengembalian kerugian keuangan negara di Kejaksaan Tinggi Sumetara Barat masih jauh dari harapan. Bahkan eksekusi dari putusan yang telah memiliki kekuatan hukum tetap pun tidak dapat dilaksanakan secara maksima.

\section{Hambatan Pelaksanaan Pengembalian Kerugian Keuangan Negara Dalam Tindak Pidana Korupsi}

Semua landasan motivasi dalam Undang-undang Tindak Pidana Korupsi dan juga KUHAP harus benar-benar diperhatikan dan dipedomani oleh semua aparat penegak hukum dalam melakukan tindakan khususnya Kejaksaan Tinggi Sumatera Barat dalam hal pengembalian kerugian negara. Hal tersebut dilaksanakan agar penegakan hukum dapat berjalan efektif dan berguna. Pihak kejaksaan dalam hal ini kejaksaan dalam lingkup Kejaksaan Tinggi Sumatera Barat berupaya semaksimal mungkin untuk bagaiman agar aset ataupun segala hal yang berhubungan dengan tindak pidana korupsi dapat dikembalikan pada negara. Betapa besar dana yang seharusnya dapat digunakan untuk kepentingan dan kemakmuran rakyat, namun akibat adanya perilaku koruptif, dana tersebut telah diselewengkan untuk kepentingan kelompok tertentu dan bahkan kepentingan pribadi. 
Disinilah peran dari kejaksaan sebagai penyidik dalam tindak pidana korupsi, berjuang keras agar dana yang telah diambil oleh para koruptor dapat disita dan bahkan dirampas untuk kepentingan Negara. Namun tidak dipungkiri bahwa kejaksaan dalam melakukan proses tersebut mengalami dan menemukan berbagai macam kendala.

Dari hasil wawancara dengan Kasi Upaya Hukum dan Eksekusi Kejaksaan Tinggi Sumatera Barat, mengungkapkan beberapa kendala antara lain (Wawancara dengan Kasi Upaya Hukuk dan Eksekusi Kejati Sumbar, 15 Januari 2011di Padang ):

1. Adanya perlawanan baik dari pihak keluarga tersangka, ataupun bahkan dari masyarakat sekitar. Korupsi sebagai salah satu kejahatan yang bersifat luar biasa (extra ordinary crime), mempunyai jaringan dan sistem yang kompleks dalam mengurai jaringannya. Keterlibatan para pihak dalam jaringan korupsi sering menghambat pemberantasan korupsi itu sendiri. Salah satu hambatan itu seperti adanya intervensi dari masyarakat dan keluarga yang mempunyai pengaruh dalam masyarakat. Hal ini sering bermasalah dalam penyitaan aset yang akan dilakukan oleh kejaksaan. Mereka tidak akan begitu saja menyerahkan aset-asetnya kepada pihak yang akan menyita atau merampasnya;

2. Jauhnya lokasi dimana barang tersebut akan disita dan juga ada saatnya barang yang akan disita telah dijual pada pihak lain; Pada kasus yang berhubungan dengan aset yang mudah untuk dipindah tangankan, sering terjadi penghilangan aset oleh koruptor dengan cara pemindahan aset yang tersangkut korupsi. Seperti pada kasus korupsi kejaksaan akan menyita mobil dari tersangaka, ternyata tersangka telah terlebih dahulu menjual mobil tersebut. Keadaan ini menyulitkan bagi kejaksaan untuk melakukan penyitaan aset.

3. Terpidana tidak sanggup membayar kerugian keuangan negara sebagaimana yang telah disebutkan dalam putusan hakim; Pada kasus tertentu dalam tindak korupsi sering ditemukan bahwa aset yang akan disita tersebut telah habis atau sudah tidak ada lagi. Pada kasus seperti itu tentu kejaksaan tidak bisa melakukan penyitaan aset terhadap pelaku korupsi. Satu-satunya jalan adalah agar terdakwa mencicil atau membayar berdasrkan kemampuan dari terpidana.

4. Terpidana lebih banyak memilih pidana kurungan (subsidair) bagi yang tidak sanggup membayar kerugian keuangan Negara. Lemahnya hukuman yang diamanatkan didalam undang-undang korupsi cenderung membuat terpidana korupsi cenderung untuk memilih hukuman subsidair daripada mengembalikan aset yang telah dikorupsi. Pada kasus ini terpidana lebih cenderung karena terpidana berpendapat bahwa pidana kurungan tersebut relatif lebih ringan daripada harus mengembalikan uang atau harta yang dikorupsi.

5. Terpidana meninggal dunia. Dalam hal pengembalian aset negara yang akan dilakukan dalam penyitaan juga terhalang dengan adanya terdakwa yang meninggal dunia, sedangkan ahli warisnya yang akan dituntut melalui gugatan perdata juga tidak mempunyai harta benda yang ditinggalkan terpidana. Hal ini terjadi karena hasil korupsi tersebut telah habis dipergunakan oleh terdakwa, sehingga harta peninggalan yang akan disita tersebut tidak ada lagi yang tersisa. 


\section{REFERENSI}

Alvi Syahrin, 2009. Beberapa Masalah Hukum, Jakarta: PT. Sofmedia.

Ermansjah Djaja, 2008, Memberantas Korupsi Bersama KPK, Jakarta: Sinar Grafika.

Deni Setyadi, 2008, KPK Pemburu Koruptor, Kiprah KomisiPemberantasan Korupsi dalam Memberangus Korupsi, Pustaka Timur, Yogyakarta.

Rohim, 2008. Modus Operandi Tindak Pidana Korupsi, Depok: Pena Multi Media.

IGM Nurdjana, 2005, Korupsi dalam Praktek Bisnis, Jakarta: Gramedia Pustaka Utama.

R. Wiyono, 2008, Pembahasan Undang-undang Pemberantasan Korupsi, Jakarta: Sinar Grafika,

Tarik Aset Pak Harto, RI minta bantuan PBB, http://www.mailarchive.com/mediacare@yahoogroups.com/msg30737.html.

Agustinus Pohan, 2008, Pengembalian Aset kejahatan, Pusat Kajian Anti Korupsi Fakultas Hukum UGM Bekerjasama dengan Kemitraan Jogjakarta.

Website Kejaksaan Tinggi Sumatera Barat, diakses Tanggal 14 Januari 2010

Chaerudin, Syaiful Ahmad Duinar, Syarif Fadillah, 2008, Strategi Pencegahan \& Penegakan Hukum Tindak Pidana Korupsi, Bandung: PT. Reflika Aditama.

Wawancara dengan Kasi Upaya Hukum dan Eksekusi (UHEK) Zulkifli, SH , Kejaksaan Tinggi Sumatera Barat, 17 Desember 2010 di Padang

Surat Edaran Mahkamah Agung RI Nomor 4 tahun 1988 